\title{
INFLUENCE OF LINEAGE OF OOCYTE DONOR ON THE YIELD AND MORPHOLOGY OF OOCYTES RECOVERED BY ULTRASOUND-GUIDED FOLLICULAR ASPIRATION IN NELLORE COWS
}

\author{
Renata Sanches Calegari ${ }^{1}$ \\ Diego Gouvêa de Souza ${ }^{2}$ \\ Daniela Martins Paschoal ${ }^{3}$ \\ Mateus José Sudano ${ }^{4}$ \\ Alicio Martins Júnior ${ }^{5}$
}

\begin{abstract}
The objective of this study was to investigate the influence of lineage of oocytes donors on the number and quality of oocytes obtained through ultrasound-guided follicular aspiration in Nellore breed cows derived from two lineages of bulls (Karvadi; K and Taj-Mahal; T). Both maternal ( $\mathrm{Km}$ and $\mathrm{Tm})$ and paternal $(\mathrm{Kp}$ and $\mathrm{Tp}$ ) lineages, as well as their combinations were investigated. Oocyte aspirations were repeatedly performed with an aspiration interval of 15 days in 56 donor females. Recovered cumulus oocyte-complexes (COCs) were counted, morphologically examined and classified into seven categories (grades from I to VII) according to the number of layers of the cumulus oocyte and cytoplasm appearance. The mean number of oocytes retrieved from donors of lineage Tp-Tm was significantly higher $(28.23 \pm 1.92, P<0.05)$ than those obtained from lineages $\mathrm{Kp}-\mathrm{Tm}, \mathrm{Kp}-\mathrm{Km}$, and $\mathrm{Tp}-\mathrm{Km}$ (21.34 $\pm 1.32,21.28 \pm 1.73$, and $16.72 \pm 1.31$, respectively). There was no significant difference in the mean number of recovered oocytes between donors of lineages $\mathrm{Kp}-\mathrm{Km}$ and $\mathrm{Kp}-\mathrm{Tm}$, whereas animals of lineage $\mathrm{Tp}-\mathrm{Km}$ yielded the lowest number of oocytes. Higher mean number of grade III oocytes was recovered from donors of lineage $\mathrm{Kp}$ than lineage $\mathrm{Tp}$ (10.11 \pm 0.66 versus $8.79 \pm 0.58$, respectively), with more grade III oocytes being obtained in both lineages as compared to the others. Paternal lineage did not influence the quality of recovered oocytes in any other category, but both $\mathrm{Kp}$ and $\mathrm{Tp}$ yielded a great mean number of oocytes graded as I, II, and III $(3.14 \pm 0.21 ; 4.93 \pm 0.33$, and $10.11 \pm 0.66$ versus $3.19 \pm 0.21$, $5.59 \pm 0.44$, and $8.79 \pm 0.58$, respectively) than those classified as IV, V, VI, and VII. However, when considering the data from the maternal lineage significantly more oocytes $(P<0.05)$ of grade I, II and III were obtained from Taj-Mahal $(11.67 \pm 0.67,5.9 \pm 0.42$ and 3.64 \pm 0.25 , respectively) than for lineage Karvadi, with similar results for oocytes of grades IV, V, VI, and VII. Similarly to the paternal lineage, the number of oocytes of grade III was superior $(P<0.05)$ when compared to other categories for both lineages. In conclusion, we demonstrate here a direct influence of lineage of oocyte donor on the production and quality of oocytes obtained through ultrasound-guided follicular aspiration in Nellore cows.
\end{abstract}

Keywords: oocyte, quality, lineage, follicular aspiration, Nellore

\footnotetext{
${ }^{1}$ Mestranda da Faculdade de Medicina Veterinária e Zootecnia - FMVZ-USP, São Paulo-SP, 05508-270, Brasil. E-mail: renatascalegari@hotmail.com

${ }^{2}$ Estagiário da Faculdade de Medicina Veterinária - FMVA - UNESP, Araçatuba-SP, 16050-680, Brasil. E-mail: diego.souza@uol.com.br

${ }^{3}$ Estagiária da Faculdade de Medicina Veterinária - FMVA -UNESP, Araçatuba-SP, 16050-680, Brasil. E-mail: dmpaschaol@yahoo.com.br

${ }^{4}$ Graduando do Curso de Medicina Veterinária, FMVZ-UNESP, Botucatu-SP, 18618-000, Brasil. E-mail: mjsudano@gmail.com

${ }^{5}$ Professor Adjunto do Departamento de Clínica, Cirurgia e Reprodução Animal, FMVA-UNESP, Araçatuba-SP, 16050-680, Brasil. E-mail: amartins@ fmva.unesp.br. Correspondência.
} 


\section{INFLUÊNCIA DA LINHAGEM DA DOADORA DE OÓCITO SOBRE A PRODUÇÃO E MORFOLOGIA DE OÓCITOS OBTIDOS PELA ASPIRAÇÃO FOLICULAR GUIADA POR ULTRASSOM EM VACAS NELORE}

\section{RESUMO}

O objetivo deste estudo foi investigar a influência da linhagem da doadora de oócito sobre o número e qualidade morfológica de oócitos obtidos através de aspiração folicular guiada por ultrassom em animais da raça Nelore, descendentes de duas linhagens de touros (Karvadi; K e Taj-Mahal; T). As linhagens maternas (Km e Tm) e paternas (Kp e Tp), e suas combinações, foram avaliadas. As aspirações de oócitos foram repetidamente realizadas em um intervalo de 15 dias em 56 doadoras. Os oócitos obtidos foram contados, analisados morfologicamente e classificados em sete categorias (graus I a VII), de acordo com o número de células do cumulus e aparência do citoplasma. O número médio de oócitos recuperados das doadoras da linhagem Tp-Tm foi significativamente maior $(28,23 \pm 1,92, \mathrm{P}<0,05)$ do que os das linhagens $\mathrm{Kp}-\mathrm{Tm}, \mathrm{Kp}-\mathrm{Km}$, and Tp-Km $(21,34 \pm 1,32 ; 21,28 \pm 1,73$ e 16,72 $\pm 1,31$, respectivamente). Não houve diferença significativa no número médio de oócitos colhidos entre as doadoras das linhagens $\mathrm{Kp}-\mathrm{Km}$ e $\mathrm{Kp}$-Tm, enquanto que animais da linhagem $\mathrm{Tp}-\mathrm{Km}$ produziram o mais baixo número de oócitos. Um maior número $(\mathrm{P}<0,05)$ de oócitos de grau III foi recuperado das doadoras da linhagem $\mathrm{Kp}$ do que da linhagem Tp $(10,11 \pm 0,66$ versus 8,79 $\pm 0,58$, respectivamente), com uma maior quantidade de oócitos de grau III sendo obtida em ambas as linhagens quando comparado com as demais. A linhagem paterna não influenciou na qualidade dos oócitos aspirados em nenhuma das categorias, mas ambas as linhagens Kp e Tp produziram um maior número de oócitos de graus I, II e III $(3,14 \pm 0,21 ; 4,93 \pm 0,33$ e $10,11 \pm 0,66$ versus $3,19 \pm 0,21 ; 5,59 \pm 0,44$ e $8,79 \pm 0,58$, respectivamente) do que aqueles classificados como de graus IV, V, VI e VII. Entretanto, quando os dados da linhagem materna foram considerados, mais oócitos $(\mathrm{P}<0.05)$ de graus I, II e III foram obtidos da linhagem Taj-Mahal $(11,67 \pm 0,67 ; 5,9 \pm 0,42$ e 3,64 $\pm 0,25$, respectivamente) do que para a linhagem Karvadi, com resultados similares para os oócitos de graus IV, V, VI e VII. Da mesma forma que a linhagem paterna, o número de oócitos de grau III foi superior $(\mathrm{P}<0,05)$ quando comparado com as categorias, nas duas linhagens. Concluindo, demonstramos a influência direta da linhagem da doadora de oócito sobre o número e qualidade dos oócitos obtidos pela aspiração folicular guiada por ultrassom em vacas da raça Nelore.

Palavras-chave: oócito, qualidade, linhagem, aspiração folicular, Nelore

\section{INFLUENCIA DEL LINAJE DE LA DONADORA DE OVOCITO SOBRE LA PRODUCCIÓN Y MORFOLOGÍA DE LOS OVOCITOS OBTENIDOS A TRAVÉS DE ASPIRACIÓN FOLICULAR GUIADA POR ULTRASONOGRAFÍA EN VACAS NELORE}

\section{RESUMEN}

El objetivo de este estudio fue investigar la influencia del linaje de las donadoras de ovocitos en el número y la calidad de los ovocitos obtenidos por aspiración folicular guiada por ecografía en animales de la raza Nelore, descendientes de dos linajes de toros (Karvadi, K y Taj-Mahal, T). Fueron evaluados los linajes maternos (Km y $\mathrm{Tm}$ ) paternos (Kp y $\mathrm{Tp}$ ) y sus combinaciones. Fueron realizadas varias aspiraciones de ovocitos en un intervalo de 15 días en 56 donadoras. Los ovocitos fueron contados, analizados morfológicamente y clasificados en siete categorías (grados I a VII) en función del número de células del cumulus y el aspecto del citoplasma. El número medio de ovocitos recuperados de donadoras del linaje Tp-Tm fue 
significativamente mayor $(28,23 \pm 1,92, \mathrm{P}<0,05)$ que los de los linajes $\mathrm{Kp}$-Tm, Kp-Km y Tp$\mathrm{Km}(21,34 \pm 1,32,21,28 \pm 1,73$ y 16,72 $\pm 1,31)$, respectivamente. No hubo diferencia significativa en el número medio de ovocitos recolectados de las donadoras $\mathrm{Kp}-\mathrm{Km}$ y $\mathrm{Kp}-\mathrm{Tm}$, mientras que los animales $\mathrm{Tp}-\mathrm{Km}$ produjeron la menor cantidad de ovocitos. Fueron recuperados más ovocitos $(\mathrm{P}<0,05)$ de grado III del linaje donador Kp que del linaje Tp $(10,11 \pm 0,66$ contra $8,79 \pm 0,58$, respectivamente), con mayor número de ovocitos grado III obtenidos en esos dos linajes en comparación con los demás. El linaje paterno no afectó la calidad de los ovocitos en ninguna de las categorías, pero ambos linajes $\mathrm{Kp}$ y Tp produjeron un gran número de ovocitos de grados I, II y III $(3,14 \pm 0,21,4,93 \pm 0,33$ y $10,11 \pm 0,66$ contra $3,19 \pm 0,21,5,59 \pm 0,44$ y $8,79 \pm 0,58$, respectivamente) de los clasificados como grado IV, V, VI y VII. Sin embargo, cuando fueron considerados los datos del linaje materno, se obtuvieron más ovocitos $(\mathrm{P}<0,05)$ para los grados I, II y III a partir del linaje de Taj-Mahal $(11,67 \pm 0,67$, $5,9 \pm 0,42$ y $3,64 \pm 0.25$, respectivamente) que del linaje Karvadi, con resultados similares a los ovocitos de los grados IV, V, VI y VII. Del mismo modo que el linaje paterno, el número de ovocitos de grado III fue mayor $(\mathrm{P}<0,05)$ en comparación con las categorías para ambos linajes. En conclusión, se demostró la influencia directa del linaje de las donadoras de ovocitos en el número y la calidad de los ovocitos obtenidos por aspiración folicular guiada por ecografía en vaquillas Nelore.

Palabras clave: ovocitos, calidad, linaje, aspiración folicular, Nelore

\section{INTRODUCTION}

The combination of ovum pick-up (OPU) and in vitro embryo production (IVP) techniques emerged as potential alternative for the classical multiple ovulation and embryo transfer (MOET), providing the multiplication of desirable genotypes in bovine populations. The first guided ultrasound follicular aspiration (OPU) was reported by Pieterse et al. (1) and provided means to explore the ovarian potential. However, successful application of OPU and IPV procedures depend initially on the number of follicles available for puncture and quality of cumulus oocyte-complexes (COCs).

There is great evidence that several factors exert considerable influence on the oocyte production (2) and quality (3) such as donor age (3, 4), nutrition (5), season $(3,6)$, besides others. However, very few studies with regard to the influence of breed on the quantity and/or quality of oocytes has been made (7), particularly when related to lineage of oocyte donor and identification through mitochondrial DNA assay (8).

During the last decades, advancements on molecular genetics have led to the identification of multiple genes or genetic markers associated to genes that affect the economic interest traits (9) including those associated to a single gene or genomic regions that affect quantitative trait loci (QTL). Thus, with bovine genome sequencing and genes for these traits available, OPU and IVP will provide a means to rapidly multiplying rare genes or QTL of high value (10). Despite the difficulties in mapping QTLs in ruminants, several traits had their variations attributed to some regions of the bovine genome, such as for milk production (11) and for ovulation rate (12). In ovine, the mapping through QTL enabled the identification of the Booroola gene (FecB) associated to the multiple ovulation rate (13).

In Brazil, Nellore breed is the most important beef cattle, which has been developed as result of many years of selective breeding from six major ancestor bulls imported from India in the decade of 60 (14). These animals have characterized their respective lineages, as evidenced by the well-defined genetic traits. However, no comparison has been described in the literature about the availability of COCs as well as their quality among lineages in this breed. Thus, the aim of this study was to investigate whether cows derived from two distinct

Calegari RS. et al. Influence of lineage of oocyte donor on the yield and morphology of oocytes recovered by ultrasound-guided follicular aspiration in nellore cows. Vet. e Zootec. 2012 dez.; 19(4): 548-556. 
lineages of Nellore bulls (Karvadi and Taj-Mahal) could further enhance the oocyte donor's performance, in terms of providing an increase in quantity and morphological quality of oocytes recovered by ultrasound- guided follicular aspiration.

\section{MATERIALS AND METHODS}

\section{Oocyte donors}

The study was carried out with animals from two farms located at the region of Araçatuba, state of São Paulo (21 ${ }^{\circ} 12^{\prime} 40^{\prime \prime} \mathrm{S}$ and 50 $53^{\prime} 21^{\prime \prime} \mathrm{W} ; 20^{\circ} 55^{\prime} 47^{\prime \prime} \mathrm{S}$ and $50^{\circ} 32^{\prime} 06^{\prime \prime}$ $\mathrm{W}$ ), belonging to the same owner. Fifty-six pure-bred Nellore cows originated from two lineages of bulls (Karvadi, K and Taj-Mahal, T) were selected as oocyte donors and randomly assigned according to maternal $(\mathrm{m})$ or paternal $(\mathrm{p})$ lineages, as well as their combinations, as follows: $\mathrm{Kp}-\mathrm{Km}(\mathrm{n}=15), \mathrm{Kp}-\mathrm{Tm}(\mathrm{n}=11), \mathrm{Tp}-\mathrm{Km}(\mathrm{n}=21)$, and Tp-Tm $(\mathrm{n}=9)$. Both farms had cows of the four combinations of lineages which, in turn, were kept under the same nutritional and health conditions throughout the experimental period (body condition score of 3.6 \pm 0.08 in a five point scale). At the beginning of the experiment the animals were also distributed evenly according to age within each group to avoid its effect (age were from 37 to 214 months old with mean of $78 \pm 12$ ). Animals were subjected to OPU sessions every 15 days over a period of 2 years.

\section{Animal and equipment preparation}

Donor females were subjected to epidural anesthesia, and then subjected to follicular puncture using a $5 \mathrm{MHz}$ vaginal convex transducer and an ultrasound scanner (Aloka SSD500, Japan) equipped with a needle guide attached to a single lumen 18 -gauge $55 \mathrm{~cm}$ long sterile needle. A vacuum pressure of $70 \mathrm{mmHg}$ was applied for oocyte recovery through use of a vacuum pump.

\section{Aspiration technique}

All the visible follicles were punctured. Continuous suction was applied and the follicular liquid and oocytes were collected in $50 \mathrm{ml}$ - centrifuge tube containing Dulbecco`s phosphate buffered saline (DPBS) supplemented with $1 \%$ fetal calf serum and $10 \mathrm{iu} / \mathrm{ml}$ heparin. At the end of the procedure, the tube containing the aspirated follicular fluid was taken to the laboratory for recovery of COCs.

\section{Oocyte classification}

COCs were evaluated under a stereomicroscope (Olympus, Japan) and classified into seven morphological categories, according to the characteristics of cumulus investment and cytoplasm, as follows: grade I, oocytes with multilayered compact cumulus oophorus and an homogeneous cytoplasm; grade II, compacted COCs with at least 3 layers of cells and homogeneous or heterogeneous cytoplasm; grade III, COCs partially denuded and/or with cytoplasm having few pyknotic areas; grade IV, mostly devoid of cumulus cells; grade V, showing expansion of cumulus cell and some signals of pyknosis; grade VI, atretic; and grade VII, degenerated oocytes.

\section{Statistical analyses}

For the statistical analyses, data from variable number of oocytes were transformed into $\log (\mathrm{x}+1)$ and subjected to analysis of variance with averages compared through the Tukey' test. Differences were considered statistically significant when $P<0.05$. The values are reported as means \pm SEM in tables. 


\section{RESULTS}

Oocyte donors derived from two unrelated lineages of bulls (Karvadi and Taj-Mahal) were investigated for their influences on the number and quality of COCs recovered by ultrasound-guided follicular aspiration. For the 56 donors, a total of 9.843 COCs were collected during 470 OPU sessions. As shown in Table 1, the mean number of oocytes retrieved from donors of lineage Tp-Tm was significantly higher $(28.23 \pm 1.92, P<0.05)$ than those obtained from lineages $\mathrm{Kp}-\mathrm{Tm}, \mathrm{Kp}-\mathrm{Km}$, and Tp-Km $(21.34 \pm 1.32,21.28 \pm 1.73$, and $16.72 \pm 1.31$, respectively).

Table 1. Number of follicular aspirations (n), total number of the aspirated oocytes (x) and mean $( \pm$ SEM) of the number of oocytes obtained by aspiration in Nellore cows, according to the paternal and maternal lineages.

\begin{tabular}{|c|c|c|c|c|c|c|}
\hline \multirow{3}{*}{ Paternal Lineage } & \multicolumn{6}{|c|}{ Maternal Lineage } \\
\hline & \multicolumn{3}{|c|}{ Karvard } & \multicolumn{3}{|c|}{ Taj-Mahal } \\
\hline & $\mathrm{n}$ & $\mathrm{x}$ & mean \pm SEM & $\mathrm{n}$ & $\mathrm{X}$ & mean \pm SEM \\
\hline Karvard & 97 & 2064 & $21.28 \pm 1.73^{\mathrm{aA}}$ & 97 & 2070 & $21.34 \pm 1.32^{\mathrm{bA}}$ \\
\hline Taj-Mahal & 181 & 3027 & $16.72 \pm 1.31^{\mathrm{bB}}$ & 95 & 2682 & $28.23 \pm 1.92^{\mathrm{aA}}$ \\
\hline
\end{tabular}

$\overline{A, B}$ - Values with different letters in the same row are significantly different $(P<0.05)$.

${ }^{a, b}$ - Values with different letters in the same column are significantly different $(P<0.05)$.

The morphological distribution of COCs regarding the lineages $\mathrm{Kp}$ and $\mathrm{Tp}$ is shown in Table 2. Higher number $(\mathrm{P}<0.05)$ of grade III oocytes was recovered per session from donors of lineage $\mathrm{Kp}$ than lineage $\mathrm{Tp}(10.11 \pm 0.66$ versus $8.79 \pm 0.58$, respectively), but the total number of oocytes graded as I, II, and III was similar between $\mathrm{Kp}$ and Tp (18.18 \pm 1.2 versus $17.57 \pm 1.23$, respectively), with more grade III oocytes being obtained in both lineages as compared to the others. Paternal lineage did not influence the quality of recovered oocytes in any other category, but both $\mathrm{Kp}$ and $\mathrm{Tp}$ yielded a great mean number of oocytes graded as I, II, and III $(3.14 \pm 0.21 ; 4.93 \pm 0.33$, and $10.11 \pm 0,66$ versus $3.19 \pm 0.21,5.59 \pm 0.44$, and $8,79 \pm 0,58$, respectively) than those other categories.

Table 2. Number of follicular aspirations (n), total number of the aspirated oocytes (x) and mean $( \pm$ SEM) of the number of oocytes obtained by aspiration in Nellore cows, according to the paternal lineages and morphological classification of oocytes.

\begin{tabular}{|c|c|c|c|c|c|c|}
\hline \multirow{3}{*}{ Grade } & \multicolumn{6}{|c|}{ Paternal Lineage } \\
\hline & \multicolumn{3}{|c|}{ Karvard } & \multicolumn{3}{|c|}{ Taj-Mahal } \\
\hline & $\mathrm{n}$ & $\mathrm{x}$ & mean \pm SEM & $\mathrm{n}$ & $\mathrm{x}$ & mean \pm SEM \\
\hline I & 194 & 609 & $3.14 \pm 0.21^{\mathrm{cA}}$ & 276 & 881 & $3.19 \pm 0.21^{\mathrm{cA}}$ \\
\hline II & 194 & 957 & $4.93 \pm 0.33^{\mathrm{bA}}$ & 276 & 1543 & $5.59 \pm 0.44^{\mathrm{bA}}$ \\
\hline III & 194 & 1962 & $10.11 \pm 0.66^{\mathrm{aA}}$ & 276 & 2427 & $8.79 \pm 0.58^{\mathrm{aB}}$ \\
\hline IV & 194 & 359 & $1.85 \pm 0.15^{\mathrm{dA}}$ & 276 & 481 & $1.74 \pm 0.16^{\mathrm{dA}}$ \\
\hline V & 194 & 22 & $0.11 \pm 0.04^{\mathrm{fA}}$ & 276 & 21 & $0.08 \pm 0.03^{\mathrm{fA}}$ \\
\hline VI & 194 & 135 & $0.70 \pm 0.08^{\mathrm{eA}}$ & 276 & 245 & $0.89 \pm 0.09^{\mathrm{eA}}$ \\
\hline VII & 194 & 90 & $0.46 \pm 0.08^{\text {efA }}$ & 276 & 111 & $0.40 \pm 0.06^{\mathrm{fA}}$ \\
\hline Total & 194 & 4134 & $21.30 \pm 1.55^{\mathrm{A}}$ & 276 & 5709 & $20.68 \pm 1.57^{\mathrm{A}}$ \\
\hline
\end{tabular}

Calegari RS. et al. Influence of lineage of oocyte donor on the yield and morphology of oocytes recovered by ultrasound-guided follicular aspiration in nellore cows. Vet. e Zootec. 2012 dez.; 19(4): 548-556. 
However, when considering the data from the maternal lineage (Table 3) significantly more oocytes $(P<0.05)$ of grade I, II and III were obtained from Taj-Mahal $(11.67 \pm 0.67$, $5.9 \pm 0.42$ and 3.64 \pm 0.25 , respectively) than for lineage Karvadi, as well as higher number of grades I, II, and III oocytes $(P<0.05)$ were found for lineage Taj-Mahal $(21.21 \pm 1.34)$ than for Karvadi (15.50 \pm 1.15$)$ with no differences between the lineages for oocytes of grades IV, V, VI, and VII. Similarly to the paternal lineage, the number of oocytes of grade III was superior $(P<0.05)$ when compared to other categories for both lineages.

Table 3. Number of follicular aspirations (n), total number of the aspirated oocytes (x) and mean $( \pm$ SEM) of the number of oocytes obtained by aspiration in Nellore cows, according to the maternal lineages and morphological classification of oocytes.

\begin{tabular}{ccrcrrr}
\hline \multirow{2}{*}{ Grade } & \multicolumn{5}{c}{ Maternal Lineage } \\
\cline { 2 - 7 } & \multicolumn{1}{c}{$\mathrm{n}$} & \multicolumn{1}{c}{$\mathrm{x}$} & mean \pm SEM & \multicolumn{1}{c}{ Taj-Mahal } \\
\hline I & 278 & 791 & $2.85 \pm 0.19^{\mathrm{cB}}$ & 192 & 699 & mean \pm SEM \\
II & 278 & 1368 & $4.92 \pm 0.40^{\mathrm{bB}}$ & 192 & 1132 & $5.90 \pm 0,25^{\mathrm{cA}}$ \\
III & 278 & 2148 & $7.73 \pm 0.56^{\mathrm{aB}}$ & 192 & 2241 & $1.67 \pm 0,67^{\mathrm{bA}}$ \\
IV & 278 & 463 & $1.67 \pm 0.15^{\mathrm{dA}}$ & 192 & 377 & $1.96 \pm 0,16^{\mathrm{dA}}$ \\
V & 278 & 20 & $0.07 \pm 0.03^{\mathrm{fA}}$ & 192 & 23 & $0.12 \pm 0,04^{\mathrm{fA}}$ \\
VI & 278 & 205 & $0.74 \pm 0.08^{\mathrm{eA}}$ & 192 & 175 & $0.91 \pm 0,10^{\mathrm{eA}}$ \\
VII & 278 & 96 & $0.35 \pm 0.05^{\mathrm{fA}}$ & 192 & 105 & $0.55 \pm 0,09^{\text {efA }}$ \\
Total & 278 & 5091 & $18.31 \pm 1.46^{\mathrm{B}}$ & 192 & 4752 & $24.75 \pm 1.73^{\mathrm{A}}$ \\
\hline
\end{tabular}

$\overline{A, B}$ - Values with different letters in the same row are significantly different $(P<0.05)$.

${ }^{a, b}$ - Values with different letters in the same column are significantly different $(P<0.05)$.

\section{DISCUSSION}

Tremendous progress has been made over the last decades in the selection of Nellore cattle in Brazil. This breed is characterized by the presence of six major bulls that contributed about $20 \%$ of genes in the formation of Brazilian Nellore cattle (14). Nellore cows derived from two lineages were evaluated to determine the number and quality of oocytes aspirated. To our knowledge, this is the first report to demonstrate a direct influence of the both maternal and paternal lineage of oocyte donors on yield and quality of COCs recovered by OPU in Nellore cows, with both parameters being affected by maternal and paternal lineage.

Many investigations on OPU have been made in several breeds, but the main efforts have been addressed to verify the influence of several nongenetics factors affecting the oocyte production and quality. Only few reports focusing on possible differences among breeds have also been reported (15). Individual variations as a result of specific and unspecific factors (5) limit the attainment of a satisfactory number of oocytes as well as oocytes with enough quality to develop in vitro after in vitro fertilization (16).

In the present study, by analyzing the results for the different combinations of lineages, it turns out that there was a greater number of oocytes recovered from donors of lineage TajMahal (maternal and paternal; Tp-Tm). This beneficial genetic effect seems to occur from the maternal lineage Taj-Mahal, as well as through the combination of animals from the same lineage $(\mathrm{Kp}-\mathrm{Km})$, as evidenced by similar number of aspirated oocytes when these lineages were combined together. Giving support for this hypothesis, when the paternal lineage TajMahal was combined with the maternal lineage Karvadi the number of recovered oocytes was significantly lower, suggesting the influence of lineage in the establishment of a quantitative trait associated to a higher availability of female gametes during OPU procedures. 
The lack of more specific information makes the comparative analysis difficult. Reports focusing on genetic factors in OPU-IVP programs are very limited (2). However, Machado et al. (17) studying the variability of OPU/IVP from monozygotic twins cows found much less variation within twin-pairs than among nonrelated cattle; they suggested the presence of genetic component and heritability of these traits. Merton et al. (2) reported, for the first time, data on heritability and genetic correlations for COCs quantity and quality.

Brüggerhorff et al. (8) reported that the number of total COCs recovered per session from two lineages of Simmental Fleckview recipients (A and B) used for somatic cell nuclear

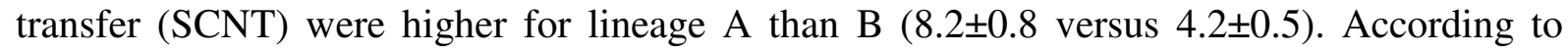
these authors the number of total recovered COCs was significantly affected by the individual donor within each maternal lineage and paternal lineage had a high influence on the fusion rates and the number of transferable embryos after SCNT. Merton et al. (2) found moderate heritability ( 0.16 to 0.40$)$ for the numeric trait (number of COCs) and low heritability for the proportional traits (quality of COCs) with number of COCs varying from 9.2 to 26.0 per session. Mahli, Adams and Singh (18) reported that related animals (mother-daughter pairs) develop equal numbers of follicular waves (two or three) during the estrous cycle. In accordance with the mentioned results

In agreement with the mentioned findings, when the morphological distribution of oocytes (grades I to VII) and the lineage of donors cows were taken in consideration, more COCs $(P<0.05)$ of grades I, II, and III were found for donors originated from maternal lineage Taj-Mahal than for cows derived from maternal lineage Karvadi. These results were not observed for donors Taj-Mahal and Karvadi of paternal origin, to which the total number of oocytes (grades I to III) were not significantly different. Similarly, the total production of oocytes (grades I to VII) was superior for cows belonging to maternal lineage Taj-Mahal $(24.75 \pm 1.73)$ than for animals from maternal lineage Karvadi (18.33 \pm 1.46$)$. This effect was not observed for paternal lineages Taj-Mahal and Karvadi. These findings clearly show an effective genetic influence on the production of better-quality oocytes (grades I to III), as well as on the total number of oocytes, mediated by the maternal lineage of the cow.

The results found in our study are in contrast with those reported by Merton et al. (2) that observed a low heritability (0.09) for quality of oocytes, suggesting that variation in distribution of COCs among different categories based on cumulus investment is mainly influenced by nongenetics factors. According to George and Anderson (19), it is a challenge elucidating the mechanisms that determinate the genetic variation of economic interest characteristics in farm animals, once they generally are influenced by the environment and are under the control of many genes. However, as the number of COCs (OPU) and the number of oocytes and embryos (MOET) share the same biological background (number of follicles present in an ovary), it is reasonable to expect a similar heritability of these traits as well (2). The significant difference for the number of oocytes recovered between the two lineages may suggest that this quantitative trait is under polygenic control with additive effects on the performance of cow donors from lineage Taj-Mahal.

The possibility of identification for these traits through a study of QTL should be considered. Evidences found in ovine demonstrate the existence of genes that affect the reproductive performance such as the gene $\mathrm{FecB}$, which was identified in Booroola sheeps in Australia (13). Relevant advancements have been observed in the last decades in relation to the application of the molecular genetics in the loci identification and regions of the chromosome containing genes that affect the production characteristics in farm animals (9). Through the QTL, several traits of economic interest, such as milk production (20) and ovulation rate in cows (12) have already been identified in the bovine genome. Thus, advancements in the molecular genetics field will allow the identification of genes and their proteins, which are expressed during different development stages of the oocyte follicle (21).

Calegari RS. et al. Influence of lineage of oocyte donor on the yield and morphology of oocytes recovered by ultrasound-guided follicular aspiration in nellore cows. Vet. e Zootec. 2012 dez.; 19(4): 548-556. 


\section{CONCLUSION}

We demonstrated here for the first time a genetic variation between two lineages of Nellore cows which influenced the number and quality of COCs recovered through ultrasound-guided follicular aspiration. Based on these experimental conditions, the lineage Taj-Mahal provided more oocytes and of better quality in comparison with lineage Karvadi. Moreover, maternal lineage seems to be the main factor to influence the production of oocytes. Further genetic investigations are required to better understand the contributions of these findings and leads encouragement to optimize OPU-PIV in bovine.

\section{REFERENCES}

1. Pieterse MC, Kappen KA, Kruip TAM, Taverne MAM. Aspiration of bovine oocytes during transvaginal ultrasound scanning of the ovaries. Theriogenology. 1988;62:1459-64.

2. Merton JS, Ask B, Onkundi DC, Mullart E, Colenbrander B, Nielen M. Genetic parameters for oocyte number and embryo production within a bovine ovum pick-up- in vitro production embryo-production program. Theriogenology. 2009;72:885-93.

3. Calegari RS, Pachoal DM, Martins Jr A. Aspiração folicular em vacas Nelore: efeitos da idade da doadora e época do ano sobre a produção e qualidade dos oócitos. Acta Sci Vet. 2006;34:477.

4. Rizos D, Burke L, Duffy P, Wade M, Mee JF, O'Farrell K, et al. Comparisons between nulliparous heifers and cows as oocyte donors for embryo production in vitro. Theriogenology. 2005;63:939-49.

5. Armstrong DG, McEvoy TG, Baxter G, Robinson JJ, Hogg CO, Woad, KJ, et al. Effect of dietary energy and protein on bovine follicular dynamics and embryo production in vitro: association with the ovarian Insuline-like growth factor system. Biol Reprod. 2001;64:1624-32.

6. Takuma T, Sakai S, Ezoe D, Ichimaru H, Jinnouch T, Kaedei Y, et al. Effects of season and reproductive phase on the quality, quantity and developmental competence of oocytes aspirated from Japanese Black cows. J Reprod Dev. 2010;56:55-9.

7. Manik RS, Singla SK, Palta P. Collection of oocytes through transvaginal ultrasoundguided aspiration of follicles in an Indian breed of cattle. Anim Reprod Sci. 2003;76:15561 .

8. Brüggerhoff K, Zakhartchenko V, Wenigerkind H, Reichenbach H, Prelle K, Schemthaner $\mathrm{W}$, et al. Bovine somatic cell nuclear transfer using recipient oocytes recovered by ovum pick-up: effect of maternal lineage of oocyte donors. Biol Reprod. 2002;66:367-73.

9. Deckers JCM. Commercial application of marker and gene assisted selection in livestock: Strategies and lessons. J Anim Sci. 2004;82:313-28.

10. Van Wagtendonk-de Leeuw AM. Ovum pick up and in vitro production in yhe bovine after use in several generations: a 2005 status. Theriogenology. 2006;65:914-25.

11. Zhang Q, Boichard D, Hoeschele I. Mapping quantitative trait loci for milk production and health of dairy cattle in a large outbreed pedigree. Genetics. 1998;149:1959-73. 
12. Arias J, Kirkpatrick B. Mapping of bovine ovulation rate QTL; an analytical approach for three generation pedigrees. Anim Genet. 2004;35:7-13.

13. Davis GH, Montgomery GW, Allison AJ. Segregation of a major gene influencing fecundity in progeny of Booroola sheep. N Z J Agric Res. 1982;25:525-9.

14. Magnabosco CU, Cordeiro CMT, Trovo JBF, Mariante AS, Lôbo RB, Josahkian LA. Catálogo de linhagens do germoplasma zebuíno: raça Nelore. Brasília: EmbrapaCenargen; 1997.

15. Rocha A, Randel RD, Broussard JR, Lim JM, Blair RM, Roussel JD, et al. High environmental temperature and humidity decrease oocyte quality in Bos taurus but not in Bos indicus cows. Theriogenology. 1998;49:657-65.

16. Hendriksen PJ, Vos PL, Steenweg WN, Bevers MM, Dieleman SJ. Bovine follicular development and its effect on the in vitro competence of oocytes. Theriogenology. 2000;53:11-20.

17. Machado SA, Reichenbach HD, Weppert M, Wolf E, Gonçalves PB. The variability of ovum pick-up response and in vitro embryo production from monozygotic twin cows. Theriogenology. 2006;65:573-83.

18. Malhi P, Adams GP, Singh J. Bovine model for the study of reproductive aging in women: follicular, luteal, and endocrine characteristics. Biol Reprod. 2005;73:45-53.

19. Georges M, Andersson L. Positional identification of structural and regulatory quantitative trait nucleotides in domestic animal species. Cold Spring Harbor Symp Quant Biol. 2003;68:179-88.

20. Ireland JJ, Ward F, Jimenez-Krassel F, Ireland JLH, Smith GW, Lonergan P. Follicle numbers are highly repeatable within individual animals but are inversely correlated with FSH concentrations and the proportions of good-quality embryos after ovarian stimulation in cattle. Hum Reprod. 2007;22:1687-95.

21. Fair T. Follicular oocyte growth and acquisition of developmental competence. Anim Reprod Sci. 2003;78:203-16. 